Arab Univ. J. Agric. Sci., Ain Shams Univ., Cairo, 14(1), 509-529, 2006

\title{
SURVEY OF MITES ASSOCIATED WITH GRAIN RESIDUES AND MIXED FLOUR IN WAREHOUSES AND MILLS IN GREAT CAIRO
}

[34]

\author{
Mahgoob $^{1}$, A.E.A.; A.I. Badawy ${ }^{1}$ and I.M. Badoor ${ }^{1}$
}

\begin{abstract}
Twenty one mite species belonging to 3 suborders and 11 families were found in grain residues and mixed flour samples collected from warehouses and mills at Great Cairo. They were 12 pest species, 7 predatory and 2 parasitic species. Species commonly found in all inspected materials at all locations were Dermatophagoides farinae Hughes, Tyrophagous putrescentiae (Sch.) and Cheyletus malaccensis Oud. However Acrus siro (Lin), Acarophenax tribolii (New.) and Pyemotes herfsi (Oud.) were often abundant. The remaining species occurred sporadically in the collected materials. Actinedid and acaridid mites were "dominant" and "constant" in mixed flour and grain residues samples, the second group was the most abundant. Whereas gamasid mites was "recedent" and "accidental". Mixed flour taken from Qaliobia Governorate harboured the highest number of mite species (15 species) followed by grain residues from Giza Governorate (13 species). While grain residues taken from Cairo Governorate harboured the lowest number ( 5 species).The highest infestation level with mites (2677.3 individuals) was recorded in mixed flour at Qaliobia Governorate, while the lowest one (1067 individuals) was found in grain residues at Cairo Governorate. Generally, mixed flour harboured more mite species than grain residues. Most of the collected mite species occurred during autumn and winter except $P$. herfsi and A. tribolii which were recorded during spring and summer, respectively. Dominance and frequency of occurrence, population fluctuations, effect of temperature and relative humidity on the population dynamics, also the relation between the predators and pests of mites were discussed in details.
\end{abstract}

Keywords: Stored products, Warehouses mills, Actinedid, Acaridid, Cheyletus, Dermatofagoides, Dominance, Population fluctuation.

\section{INTRODUCTION}

Mites are important pests of stored products particularly in temperate regions of the world (Hall, 1970 and Sinha,
1973). They cause serious economic losses by feeding directly on the germs of stored cereals resulting in the loss of their viability as seeds (Hughes, 1961 and White et al 1979). Mites also serve as

1- Department of Plant Protection, Faculty of Agriculture, Ain Shams University, Shoubra El-Kheima, Cairo, Egypt

(Received November 26, 2005)

(Accepted December 7, 2005) 
vectors of several kinds of moulds and bacteria (Zdarkova, 1967).

Several studies on survey and population densities were conducted on mite pests infesting stored grain products in warehouses and mills. Li et al (1997) found that 79 mite species belonging to four orders and 25 families infested food stuffs including grains. Tyrophagous putrescentiae (Sch.) was the most common species. Aleuroglyphus ovatus Troup, Suidasia nesbitti Hughes and Lepidoglyphus destructor (Sch.) some times occurred in great numbers. Zdarkova (1998) collected mites from wheat and barely as well as sweeping from stores. Thirty two species were found belonging to three suborders. Dominant species were L. destructor and A. siro (Lin.).

In Egypt, some investigators studied the mite fauna in stored products (Wafa et al 1966a \& 1966b; Zaher \& Soliman, 1971; Hafez; 1977; Zaher et al 1986 and Hoda et al 1990). Ten predatory species belonging to two orders and three families were collected from stored food materials. Two parasitic species belonging to one order and one family were also recorded. The cheyletids were the most common mite species. (Hafez, 1977). Zaher et al (1986) mentioned that 24 species belonging to three suborder and 13 families were found in seeds, grains and other stored products taken from granaries and flour mills. Members of Cheyletidae and Acaridae were the most common mites. Hoda et al (1990) also surveyed mites in cereals, wheat flour, wheat straw and rice hay and found 23 species of prostigmatid mites belonging to six families'

Most of warehouses, flour mills and grain markets lack sanitation, and thus allow the development of several of stored product pests. The breakage of grains into fragments and finally into flour results in particles too small provide an ideal media for mite infestation to become a good source of re-infestation. therefore the objective of the present work are to survey the mite fauna in grain residues and mixed flour samples collected from warehouses and mills in great Cairo region. Also to study the dominancy and frequency of occurrence, population fluctuation, effect of the temperature and relative humidity on the population dynamics on the collected mite fauna. The relationship between the predacious and pests of the collected mite species in their materials and locations was in consideration.

\section{MATERIAL AND METHODS}

One- year field survey was carried out in three locations at Great Cairo Region to study the prevalence of stored product mites encountered in grain residues and mixed flour. Grain residues here refer to all leftover grains, insect-damaged grains, mechanically broken grains, waste grains and those containing foreign matter. Mixed flour refer to flour of unknown origin (wheat, maize or barley) scattered on the mill floor and usually mixed with dust and sweepings. Two samples/month (one each 2 weeks) of grain residues and mixed flour (1 kg each) were respectively taken from three warehouses and three mills located in Cairo, Giza and Qaliobia Governorates during Mar. 2003 to Feb. 2004. The collected samples were kept in cloth bags, and transferred to the laboratory for mite extraction at the same day.

Each sample was carefully mixed and about $100 \mathrm{gm}$ spread over muslin in the Tullgren (modified Berlese ) funnels in 
$2 \mathrm{~cm}$ deep layers. The extracted mites were received in Petri dishes filled with about $25 \mathrm{~cm}$ of tap water. Twenty - four hours later extraction contents of the Petri dishes were examined by using the dissecting microscope. Adults and immature stages of mites were mounted on microscopic glass slides in modified Berlese fluid (Schuster and Pritchard, 1963) for identification and counting by using light microscope. Number of mites in each sample was attributed to one kg.. The identification of mites was carried out to the families and species level (The mature females were used to recognize the species) using keys erected by Attiah (1969); Cross \& Moser (1975); Hughes (1976); Krantz (1978); Zaher (1986); Volgin (1987) and Rady (1998). The taxa found were described using the criteria of frequency and dominance as well as the symbols denoting degree of infestation used by Cusack et al (1975). This was summarized in Tables (1 and 2) as follows:

\section{Dominancy}

$\mathrm{D}=$ Dominant $=$ species forming more than $11.1 \%$ of the total mite population.

$\mathrm{I}=$ Influent $=$ species forming between 5.6 and $11.1 \%$ of the total mite population.

$\mathrm{R}=$ Recedent $=$ species forming less than $5.6 \%$ of the total mite population.

\section{Frequency}

$\mathrm{C}=$ constant $=$ occurring in more than $50 \%$ of samples.

AS $=$ Accessory $=$ occurring in $25-50 \%$ of samples

$\mathrm{AD}=$ Accidental $=$ occurring in less than $25 \%$ of samples.
To investigate the effects of some ecological factors on the population dynamics of the most common mite species found in grain residues and mixed flour, simple correlation and partial regression between the temperature, relative humidity and the population density of each species (C-multiple formula) were carried out according to Fisher, 1950 records of daily main temperature and relative humidity\% were taken from records available from Metrological Stations.

\section{Statistical Analysis}

The collected data were subjected to the proper statistical analysis of complete randomized design according to procedure outlined by Snedecor and Cochran (1980). L.S.D. at 5\% level of probability was used to compare between means according to Waller and Duncan (1969). Simple correlation between the malformation percentages and number of mites existing buds of mango varieties was calculated. Also population estimation was correlated with temperature and relative humidity records available from Metrological Stations.

\section{RESULTS AND DISCUSSION}

This survey was undertaken to assess the size and mite composition found in grain residues and mixed flour collected from warehouses and mills in Great Cairo. The obtained results revealed that, twenty one mite species were recorded. Eleven of them were found in both examined materials. The mite species were Acarus siro (Lin.), Caloglyphus rizhoglyphoides, Suidasia nesbitti Hughes and Tyrophagous putrescentiae (Sch.) (Fam.: Acaridae); Blomia freemani, 
Glycyphagus destructor (Sch.), G. oryzae Attiah and Goheria fusca (Oud.) (Fam.: Glycyphagidae); Dermatophagoides africanus and D. farinae Hughes (Fam.: Pyroglyphidae) and Chortoglyphus sp. (Fam.: Chortoglyphidae). All the above mentioned mite species belonging to suborder Astigmata. Cheyletus malaccensis Oud., C. eruditus (Sch.), Acaropsis solers and Ker bakeri (Zaher and Soliman) (Fam.: Cheyletidae); Acarophenax tribolii (New.) (Fam.: Acarophenacidae); Pyemotes herfsi (Oud.) (Fam.: Pyemotidae); Cunaxa capreolus Berl. (Fam.: Cunaxidae); Tarsonemus sp.(Fam.: Tarsonemidae); Kleemania plumigera Oud. (Fam.: Ameroseiidae) and Hypoaspis $(H$. smithi (Fam.: Laelapidae). All the previous mite species belonging to suborder Prostigmata except the last two ones belonging to suborder Mesostigmata. (Table 2)

\section{Dominancy and frequency of occur- rence}

\section{A- In mixed flour}

Number of mite species, their dominancy and frequency in the mixed flour samples collected from mills at Cairo, Giza and Qaliobia Governorates are given in Table (1). Seventeen mite species were found, 8 of them (C. malaccensis, G. fusca, S. nesbitti, Chortoglyphus sp., G. oryzae, G. destructor, B. freemani and $H$. (H.) smithi) only were recorded at Qaliobia Governorate. Also C. rizhoglyphoides and D. africanus were only recorded at Cairo Governorate but $A$. solers was recorded at Giza Governorate. On the other hand $P$. herfsi were found at Giza and Qaliobia Governorates. All the above mentioned mite species were "rec- edent" and "accidental" except $C$. eruditus and A. solers were "recedent" and "accessory". The percentages of their total mite population ranged between $0.1 \%$ to $3.8 \%$ while the percentages of their occurrence in the collected samples ranged between $8.3 \%$ to $25 \%$.

The most common mite species collected from mixed flour were, D. farinae, C. malaccensis, A. tribolii, A. siro and T. putrescentiae were recorded at all governorates. D. farinae was "dominant" and "constant" because it represented by $49.2 \%, 33.4 \%$ and $39.2 \%$ of the total mite population and occurred by $100 \%, 58.3 \%$ and $100 \%$ in the collected samples at Cairo, Giza and Qaliobia Governorates respectively. Similarly $C$. malaccensis was "influent" and "accessory" because it represented by $5.6 \%, 7.9 \%$ and $6.2 \%$ of the total mite population and occurred by $50 \%, 41.7 \%$ and $41.7 \%$ in the collected samples at Cairo, Giza and Qaliobia Governorates respectively. A. tribolii was "dominant" at all Governorates but "constant" at Cairo only and "accessory" at Giza and Qaliobia Governorates, its percentage of the total mite population ranged between $19.6 \%$ to $37.2 \%$ while the percentage of its occurrence ranged between $25 \%$ to $58 \%$.

T. putrescentiae was "recedent" and "accidental" at Giza and Qaliobia Governorates whereas it was "influent" and "accessory" at Cairo Governorate. A. siro was "constant" and "accessory" at Qaliobia and Giza Governorates respectively but was "dominant" at both of them. However it was "recedent" and "accessory" at Cairo Governorate.

Regardless the locations, data in Table (2) revealed that prostigmatid and astigmatid mites were "dominant" and "constant" in mixed flour samples, the second 
group was the most abundant. However, their percentage of the total mite population and percentage of occurrence were $36.6 \%$; $69 \%$ and $63.3 \%$; $97.2 \%$ respectively. Also $D$. farinae and $A$. siro were "dominant" and "constant"; C. malaccensis was "influent" and "constant" but $A$. tribolii was "dominant" and "accessory" in all the inspected mixed flour samples. The rest of mite species were "recedent" and "accidental".

\section{B- In grain residues}

The present data in Table (1) indicated that, 15 mite species were found in the samples of grain residues at Cairo, Giza and Qaliobia Governorates. The dominancy and frequency of the recorded mite species were as following. $K$, bakeri, $C$. capreolus, Chortoglyphus sp., D. africanus and $H$. (H.) smithi were "recedent" and "accidental", their percentage of the total mite population ranged between $0.3 \%$ to $1.5 \%$ and they were occurred with a percentage of $8.3 \%$ in the total samples collected from Giza Governorate. B. freemani was "influent" and "accessory", while $K$. pulmigera was "recedent" and "accidental", the previous two mite species only recorded at Qaliobia Governorate.

The collected samples from Giza and Qaliobia Governorates were contaminated with $A$. tribolii which was "influent" and "accidental" at Giza Governorate but "accidental" at Qaliobia Governorate, meanwhile Tarsonemus sp. Was "recedent" and "accidental" at both Governorates. Similarly there were two mite species recorded at Cairo and Giza Governorates, the first one (A. solers) was "recedent" and "accidental" at both Governorates, whereas the second one ( $A$. siro) was "influent" and "accessory" at Cairo Governorate but "dominant" and "constant" at Giza Governorate.

Obviously it could be observed that, there were three mite species found in the samples of grain residues at all Governorates. T. putrescentiae was "recedent" and "accidental" with a percentage of total mite population ranged between $0.9 \%$ to $8.3 \%$ and occurred in $8.3 \%$ of the collected samples. However C. malaccensis and $D$. farinae were "dominant" and "constant" at Cairo and Qaliobia governorates but "dominant" and "accessory" at Giza Governorate. The percentage of total mite population ranged between $14.6 \%$ to $31.1 \%$ and $20.8 \%$ to $60.7 \%$ whereas the percentage of the occurrence in the collected samples ranged between $50 \%$ to $83.3 \%$ and $41.7 \%$ to $91.3 \%$ of the aforementioned species respectively. It could be observed that, the most common mite species in grain residues were $C$. malaccensis, D. farinae, A.siro, A. tribolii, P. herfsi and T. Putrescentiae.

The previous results are in agreement with the findings of Emmanouel et $\boldsymbol{a l}$ (1994) who found that 17 mite species from 11 families and four orders associated with (wheat, maize, barley, wheat flour, bran and residues) in three types of storage facilities (silos, farm stores and flour mills). Also Mahmood (1992) mentioned that 16 mite species were found in wheat, barley and rice. Of which, eight belonged to Mesostigmata, four to Astigmata, three to Prostigmata and one to the Cryptostigmata. Hafez (1977); Genc \& Ozar (1986); Mahmood (1992); El-Lakwah et al (1993); Emmanouel et al (1994); Zdarkova (1998) and Halawa (2003) said that $C$. malaccensis, $C$. eruditus, D. farinae,, T. putrescentiae and $A$. 
Arab Univ. J. Agric. Sci., 14(1), 2006 
siro were the most common and dominant mite species in stored products and the most infested product with mites was wheat flour.

Irrespective of the locations, prostigmatid and astigmatid mites were "dominant" and "constant" in all examined samples of grain residues; however their dominancy and frequency were about quite similar. The percentage of total mite population and percentage of occurrence in the total collected samples were $48.2 \%$; $83.3 \%$ and $51.5 \%$; $86.1 \%$ respectively. C. malaccensis and D. farinae were "dominant" and "constant"; $P$. herfsi was "dominant" and "accidental" while A. siro was "dominant" and "accessory". The other mite species were "recedent" and "accidental". Mesostigmatid group was "recedent" and "accidental" too and represented with only two mite species (K. pulmigera and $H$. (H.) smithi). Only, K. bakeri, $C$. capreolus, Tarsonemus sp., and $K$. pulmigera were found in grain residues while C.eruditus, C. rihzoglyphoides, S. nesbitti, G. oryzae, G. destructor, G. fusca and B. freemani were found in mixed flour. However the other mite species were found in both examined materials. Finally mixed flour samples harboured more mite species than grain residues. (Table 2). The previous observation strongly supported by the following authors, Zdarkova \& Horak (1990) and Zdarkova (1998) surveyed the mite fauna in 26 empty agriculture warehouses and found that, astigmated pests were found in $76.9 \%$ of stores. The prostigmated and astigmatid mites were the most dominant mites among the collected mite species.

Data in Table (3) indicated that the highest numbers of total mite infested mixed flour samples were found during
Nov., Sept., and Jan. while the lowest numbers were found during Apr., Mar. and Apr. at Cairo, Giza and Qaliobia Governorates respectively. Similarly the highest numbers of total mites infested grain residues were found during Feb., Nov., and Apr. whereas the lowest numbers were found during Apr., June and Sept. at Cairo, Giza and Qaliobia Governorates respectively.

It could be mentioned that, the highest numbers during May, June, July and Aug. in mixed flour attributed to the increased numbers of $A$. tribolii. Also the higest numbers during Apr., May and June in grain residues only at Qaliobia governorate attributed to the increased numbers of $P$. herfsi,(see population fluctuations). Irrespective of the previous observation it could be concluded that, generally stored product mites were more abundant during the seasons of autumn, winter and spring than summer.

Regarding to the levels of mite infestation between the inspected locations or materials, statistical analysis indicated that, in mixed flour samples there was no significant differences in the mite infestation between Cairo and Qaliobia Governorates but both of them had significant differences than Giza Governorate. However Qaliobia Governorate was significantly difference of the mite infestation than others in the samples of grain residues. Furthermore mixed flour was highly significant difference than grain residues in mite infestation. However the differences in abundance of mite population or its levels of infestation in different materials or locations could be attributed to the absence of control pests, sanitation, and presence of some natural enemies or some other factors (Emmanoule et al 1994 and Halawa 2003). 
Table 2. Domenancy and Frequency of stored product mite taxa found in mixed flour and grain residues samples collected from great Cairo region during the period from Mar.2003 to Feb. 2004.

\begin{tabular}{|c|c|c|c|c|c|c|c|c|c|}
\hline & & & & & Stored & products & & & \\
\hline & Mite Taxa & & Mixed & Flour & & & Grain $\mathrm{F}$ & esidues & \\
\hline & Nille laxa & $\begin{array}{c}\% \text { of total } \\
\text { mites }\end{array}$ & $\begin{array}{c}\text { Domin- } \\
\text { ance }\end{array}$ & $\begin{array}{c}\% \text { of occ- } \\
\text { urrence }\end{array}$ & $\begin{array}{c}\text { Frequ- } \\
\text { ency }\end{array}$ & $\begin{array}{c}\% \text { of total } \\
\text { mites }\end{array}$ & $\begin{array}{c}\text { Domin- } \\
\text { ance }\end{array}$ & $\begin{array}{c}\% \text { of occ- } \\
\text { urrence }\end{array}$ & $\begin{array}{c}\text { Frequ- } \\
\text { ency }\end{array}$ \\
\hline $1-$ & S. O. Actinedida & 36.6 & $\mathrm{D}$ & 69.4 & $\mathrm{C}$ & 48.2 & $\mathrm{D}$ & 83.3 & $\mathrm{C}$ \\
\hline & 1- Fam. Cheylitedae & 7.6 & I & 55.6 & $\mathrm{C}$ & 22.3 & $\mathrm{D}$ & 75 & $\mathrm{C}$ \\
\hline & 1 C. malaccensis & 6.4 & I & 50 & AS & 21.5 & $\mathrm{D}$ & 78.1 & $\mathrm{C}$ \\
\hline & 2 C. eruditus & 0.7 & $\mathrm{R}$ & 9.4 & $\mathrm{AD}$ & & & & \\
\hline & 3 A. solers & 0.6 & $\mathrm{R}$ & 9.4 & $\mathrm{AD}$ & 0.33 & $\mathrm{R}$ & 6.3 & $\mathrm{AD}$ \\
\hline & $4 \quad$ K. bakeri & & & & & 0.51 & $\mathrm{R}$ & 3.1 & $\mathrm{AD}$ \\
\hline & 2- Fam. Acaophenacidae & 28.2 & $\mathrm{D}$ & 36.1 & AS & 4.1 & $\mathrm{R}$ & 8.3 & $\mathrm{AD}$ \\
\hline & A. tribolii & 28.3 & $\mathrm{D}$ & 73.8 & AS & 4.1 & $\mathrm{R}$ & 9.4 & $\mathrm{AD}$ \\
\hline & 3- Fam. Pyemotidae & 0.8 & $\mathrm{R}$ & 8.3 & $\mathrm{AD}$ & 21.3 & $\mathrm{D}$ & 19.4 & $\mathrm{AD}$ \\
\hline & P. herfsi & 0.8 & $\mathrm{R}$ & 9.4 & $\mathrm{AD}$ & 21.3 & $\mathrm{D}$ & 21.9 & $\mathrm{AD}$ \\
\hline & 4- Fam. Cunaxidae & & & & & 0.1 & $\mathrm{R}$ & 2.8 & $\mathrm{AD}$ \\
\hline & C. capreolus & & & & & 0.08 & $\mathrm{R}$ & 3.1 & $\mathrm{AD}$ \\
\hline & 5- Fam. Tarsonemidae & & & & & 0.4 & $\mathrm{R}$ & 8.3 & $\mathrm{AD}$ \\
\hline & Tarsonemus sp. & & & & & 0.4 & $\mathrm{R}$ & 9.4 & $\mathrm{AD}$ \\
\hline $2-$ & S. O. Acaridida & 63.3 & $\mathrm{D}$ & 97.2 & $\mathrm{C}$ & 51.5 & $\mathrm{D}$ & 86.1 & $\mathrm{C}$ \\
\hline & 1- Fam. Acaridae & 17.9 & $\mathrm{D}$ & 47.2 & AS & 13.2 & $\mathrm{D}$ & 47.2 & AS \\
\hline & 1 A. siro & 13 & $\mathrm{D}$ & 53.1 & $\mathrm{C}$ & 11.3 & $\mathrm{D}$ & 34.4 & AS \\
\hline & 2 C. rizhoglyphoides & 0.2 & $\mathrm{R}$ & 3.1 & $\mathrm{AD}$ & & & & \\
\hline & 3 S. nesbitti & 0.08 & $\mathrm{R}$ & 3.1 & $\mathrm{AD}$ & & & & \\
\hline & $4 T$. putrescentiae & 4.7 & $\mathrm{R}$ & 21.9 & $\mathrm{AD}$ & 2 & $\mathrm{R}$ & 15.6 & $\mathrm{AD}$ \\
\hline & 2- Fam. Chortoglyphidae & 0.1 & $\mathrm{R}$ & 2.8 & $\mathrm{AD}$ & 0.2 & $\mathrm{R}$ & 2.8 & $\mathrm{AD}$ \\
\hline & Chortoglyphus sp. & 0.06 & $\mathrm{R}$ & 3.1 & $\mathrm{AD}$ & 0.15 & $\mathrm{R}$ & 3.1 & $\mathrm{AD}$ \\
\hline & 3- Fam. Glycyphagidae & 3.2 & $\mathrm{R}$ & 2.8 & $\mathrm{AD}$ & 2.5 & $\mathrm{R}$ & 5.6 & $\mathrm{AD}$ \\
\hline & 1 G. oryzae & 1.6 & $\mathrm{R}$ & 3.1 & $\mathrm{AD}$ & & & & \\
\hline & 2 G. destructor & 0.06 & $\mathrm{R}$ & 3.1 & $\mathrm{AD}$ & & & & \\
\hline & 3 G. fusca & 0.06 & $\mathrm{R}$ & 3.1 & $\mathrm{AD}$ & & & & \\
\hline & 4 B. freemani & 1.5 & $\mathrm{R}$ & 3.1 & $\mathrm{AD}$ & 2.5 & $\mathrm{R}$ & 9.4 & $\mathrm{AD}$ \\
\hline & 4- Fam. Pyroglyphidae & 42.1 & $\mathrm{D}$ & 86.1 & $\mathrm{C}$ & 35.5 & $\mathrm{D}$ & 66.6 & $\mathrm{C}$ \\
\hline & 1 D. farinae & 41.5 & $\mathrm{D}$ & 96.9 & $\mathrm{C}$ & 35.4 & $\mathrm{D}$ & 71.9 & $\mathrm{C}$ \\
\hline & 2 D. africanus & 0.6 & $\mathrm{R}$ & 6.3 & $\mathrm{AD}$ & 0.19 & $\mathrm{R}$ & 3.1 & $\mathrm{AD}$ \\
\hline $3-$ & S. O. Gamasida & 0.1 & $\mathrm{R}$ & 2.8 & $\mathrm{AD}$ & 0.3 & $\mathrm{R}$ & 5.6 & $\mathrm{AD}$ \\
\hline & 1- Fam. Amerosiidae & & & & & 0.2 & $\mathrm{R}$ & 2.8 & $\mathrm{AD}$ \\
\hline & K. pulmigera & & & & & 0.15 & $\mathrm{R}$ & 3.1 & $\mathrm{AD}$ \\
\hline & 2- Fam. Laelapidae & 0.1 & $\mathrm{R}$ & 2.8 & $\mathrm{AD}$ & 0.2 & $\mathrm{R}$ & 2.8 & $\mathrm{AD}$ \\
\hline & H. (H.) smithii & 0.08 & $\mathrm{R}$ & 3.1 & $\mathrm{AD}$ & 0.15 & $\mathrm{R}$ & 3.1 & $\mathrm{AD}$ \\
\hline & No. Of Species & 17 & & & & 15 & & & \\
\hline
\end{tabular}




\section{2- Population fluctuation}

The previous survey revealed that, mite species of $D$. farinae and A. siro were the most common mite pests while C. malaccensis, A. tribolii and P. herfsi were the most common natural enemies found in the examined materials. Their population fluctuations will be declared to get better understanding about their normal distribution in their natural habitat.

\section{A. In mixed flour}

Data in Fig. (1-A) Show that the highest numbers of $D$. farinae were noticed during Nov. and Dec. at all locations. While the lowest ones were recorded during Mar. in Cairo and Giza governorates, respectively. Apr., May, June, July and Feb. were free of mites in Giza Governorate. However the populations of $D$. farinae follow almost the same trend at all locations. At the beginning of Apr. the populations were in low levels (Apr. to June), then increased at the beginning of July (July to Oct.). Moreover, sharply increased in Cairo and Qaliobiah Governorates to reach their peaks in Nov. A moderate increase in population was observed in Cairo Governorate. However a sudden decrease started from Dec. at all locations. Noteworthy to mention that, spring and summer seasons had the lowest populations whereas autumn and winter seasons had the highest ones

In the case of $A$. siro (Fig.1-B) revealed that its population in Qaliobiah Governorate was higher than in the other locations. Two peaks of high size were recorded in Qaliobiah Governorate during June and Jan., while another three moderate peaks were recorded in Giza Governorate during June and Feb. Cairo Gover- norate had one moderate peak recorded during Jan. However, Oct., Nov. and Dec. were free of mites at all locations. The lowest average number of mites was 8.3, while the highest one was 297.5 mites per one $\mathrm{kg}$. recorded in Cairo and Qaliobiah governorates, respectively.

In the three governorate, abundance of C. malaccensis differed greatly in the different seasons. During the period from May to Nov., there were a few and scattered peaks at all locations. The previous peaks were moderate in their size. The highest peaks were found in Cairo during Dec. and Jan. Also there were another three peaks found in Qaliobiah Governorate during Mar., Jan. and Feb. respectively. The highest peak found in Giza was recorded during Feb. It could be observed that most of the moderate peaks recorded during spring whereas the highest ones recorded during winter at all inspected locations. On the opposite, most of summer and autumn months were free of mites except a few of them had moderate and small peaks. (Fig.1-C).

Concerning of the parasitic mite $A$. tribolii Fig. (1-D) revealed that the populations were abundant during the period from May to Sept. There were two peaks recorded in Giza during May and Sept. and another two peaks during May and Aug. in Qaliobia Governorate. Four peaks were recorded also in Cairo Governorate during the period from May to Aug. Noteworthy to mention that the highest population concentrated mainly during summer season. On the other hand spring, autumn and winter were mostly free of mites except a few ones

\section{B- In grain residues}

The seasonal fluctuations in the numbers of D. farinae are shown in Fig. (2-A) 
Arab Univ. J. Agric. Sci., 14(1), 2006 
The highest numbers were recorded during the period from Oct. to Feb. mostly at all inspected locations. However Giza Governorate was free of mites during the period from Mar. to Aug. Similar observation was recorded in Qaliobiah Governorate, but there were two peaks in Mar. and July. On the opposite Cairo Governorate had considerable numbers within the same period except in Apr. Generally spring and summer seasons had low levels of mite populations, whereas autumn and winter seasons had higher levels. At the beginning of Sept. populations started to increase sharply to reach its peaks in Oct., Nov. and Dec. in Qaliobiah, Giza and Cairo governorates, respectively, then started to decrease gradually at the beginning of Jan.

Regarding the species A. siro, Qaliobiah Governorate was free of mites during the inspected period, while there were few and scattered small peaks found in Cairo Governorate. With regard to Giza Governorate, there were four peaks, most of them were recorded during autumn and winter seasons. The highest ones of these peaks were recorded in Sept., Jan. and Feb. Most of spring and summer months were free of mites except May and Aug. (Fig.2-B).

The seasonal fluctuations in the numbers of $C$. malaccensis are shown in Fig. (2-C). the highest numbers were recorded during Jan. and Feb. mostly at all locations. The highest number was recorded in Giza Governorate during Feb. while the lowest one was recorded in Qaliobiah during Dec. Giza Governorate was free of mites during Mar., Apr., Sept. and Oct. However Spring, summer and autumn had low levels of mite populations, while winter season had higher levels. It could be noticed that the highest peaks were recorded during Jan. and Feb. in Cairo and Qaliobiah Governorates, but in Giza was only in Feb. Also, Cairo and Qaliobiah had higher populations than Giza.

Regarding the parasitic mite $P$. herfsi Fig. (2-D).revealed that two major peaks were recorded during Mar. and Apr. with a small one was recorded during June in Giza Governorate. Similar observation was recorded in Qaliobiah Governorate. The rest of the months in both governorates, also Cairo Governorate were free of mite. It could be observed that the highest mite population was recorded during spring months, then sharply decrease started at the beginning of June. autumn and winter were free of that parasitic mite ( $P$. herfsi).

The obtained data indicated that the most common mite pests (D. farinae and A. siro) were abundant mainly during autumn and winter in both mixed flour and grain residues. Similar results were found by Wafa et al (1966b) and Mahmood (1992) who mentioned that some acarid mite species such as Tyrophagus sp. occurred mainly during autumn and winter. C. malaccensis, A. tribolii and $P$. herfsi were the most abundant predaceous and parasitic mites. However. C. malaccensis was highly abundant during winter, but moderately abundant in spring and summer in both examined materials at all locations. On the other hand $P$. herfsi occurred only in spring at all locations, but $A$. tribolii occurred mainly in summer. The aforementioned results were in agreement with the findings of Wafa et al (1966b) and Mahmood (1992) who found that the population density of Melicharis sp. and Cheyletus sp. reached their maximum peaks during the period from Dec. to Feb., while Pyemotes sp. and Acaro- 
phenax sp. began to appear relatively late during Jan. and Feb. until July. Grain residues had higher population of $P$. herfsi than A. tribolii, while the opposite was found in mixed flour. This may be attributed to the presence of heavy infestation by stored product Coleoptera and Lepidoptera (Emmanouel et al 1994).

\section{3- Effect of temperature and the rela- tive humidity on the population dy- namics of the main stored products mites found in mixed flour and grain residues}

Temperature and relative humidity (RH\%) were tested to clarify their effects on the population dynamics of $D$. farinae, A. siro, C. malaccensis, A. tribolii and $P$. herfsi. The average numbers of mite species / $1 \mathrm{Kg}$. (twice a month) were used as dependent factor (Y), while corresponding means of the two selected factors were used as independent. The effect of each factor separately was obtained by applying simple correlation while the combined effects of these factors were estimated by $\mathrm{C}$-multiplies formula and expressed as percentage of explained variance.

Data given in Table (4) revealed that, in general temperature and $\mathrm{RH} \%$ had negative significant or insignificant effects and sometimes positive insignificant effects on the population dynamics of all the subjected mite species. However the temperature had negative significant effect on the population dynamics of $C$. malaccensis found in grain residues at Qaliobea Governorate and mixed flour at Cairo governorate. Correlation coefficient values were -0.65 and -0.5 . Also an other negative significant effect of the temperature was observed on population A. siro in mixed flour at Cairo and Qaliobia Governorates but in Grain residues at Giza Governorate. Correlation coefficient was -0.4 at all locations. Temperature had negative insignificant effect on the population of $D$. farinae, while $\mathrm{RH} \%$ had a positive insignificant effect on the same species at the most of all locations in both examined materials. In case of parasitic mites the effect of temperature and $\mathrm{RH}$ were not clear, however this could be attributed to their relation with their hosts.

From the obtained results could be observed that the negative effect of the temperature in addition to some other factors on the population dynamics of some stored product mites may be explain why these mites has low levels of its populations during the summer but had high levels in autumn, spring and winter seasons. However, Bruce (1984) studied the effect of temperature and humidity on the survival and fecundity of $P$. tritici under laboratory condition and found that the survival of adult females was negatively related to temperature and positively related to humidity. When a host was parasitized, relative humidity did not appear to be as critical as temperature in the production of mite offspring. Relatively high numbers of offspring per female were obtained in the temperature range $19-28^{\circ} \mathrm{C}$ and above $30 \%$ R.H. While, Matsumoto et al (1998). Studied the effect of various environmental conditions on the dispersion of some astigmatid mites and found that $T$. putrescentiae, $A$. ovatus and D. farinae were dispersed more actively at low humidity than at high humidity. With regard to the effect of temperature on the dispersion of the mites, he found that. G. domesticus and A. immobilis, were more 
Arab Univ. J. Agric. Sci., 14(1), 2006 
actively dispersed at a high temperature $\left(35^{\circ} \mathrm{C}\right)$, while $T$. putrescentiae, became active at low temperatures $\left(15^{\circ} \mathrm{C}\right.$ or $\left.20^{\circ} \mathrm{C}\right)$.

\section{The relationship between the preda- cious and pests of the collected mite species}

Concerning the relationship between mite pests and predators Fig. (3), obviously revealed that mite predators were found in grain residues with relatively a higher numbers at all location than the ones in mixed flour samples, which re- flected on a reduction of the numbers of mite pests in grain residues than the ones in mixed flour. Also it could be observed that in Figs. $1 \& 2$ ( A, B and C), the months which had a higher numbers predator had a lower numbers of pests. However the obtained results confirmed the role of mite predators as biocontrol agents. Moreover Zdarkova et al (1997) mentioned that $C$. eruditus had been successfully used to prevent mite infestations in empty stores and prevent or repress pest populations in grain or seed.

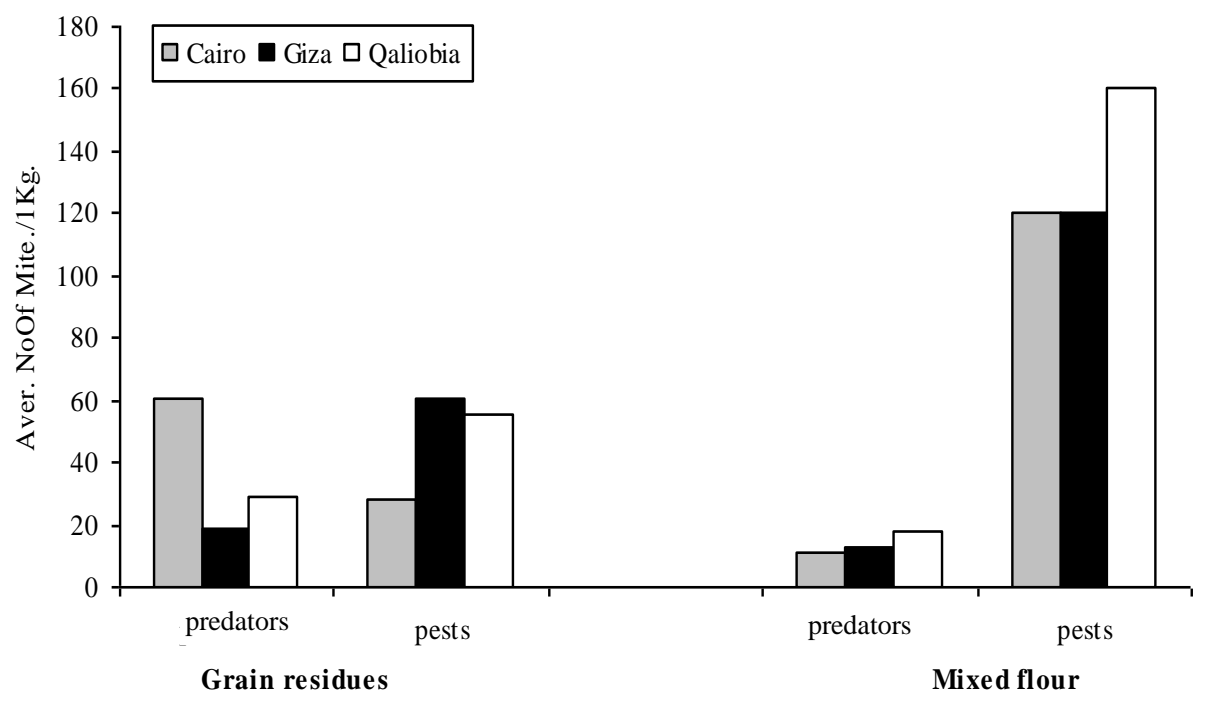

Fig. 3. The relationship between the incedince of mite pests and predators found in grain residues and mixed flour collected from Cairo, Giza and Qaliobia Governorate

\section{REFERENCES}

Attiah, H.H. (1969). Tyroglyphid mites associated with stored food in U.A.R.
Minst. of Agric. U.A.R. Dokki, Cairo. Tech. Bull., No. 10, $51 \mathrm{pp}$.

Bruce, W.A. (1984). Temperature and humidity effects on survival and fecundi- 
ty of Pyemotes tritici (Acari: Pyemotidae). International J. Acarol., 10 (3): 135-138.

Cross, E.A. and J.C. Moser. (1975). A new dimorphic species of pyemotes and a key to previously described forms (Acarina: Tarsonemoidea). Ann. Entomol.Soc. Amer. 68: 723-732.

Cusak, P.D.; G.O. Evans and P.A. Brennan (1975). A survey of the mites of stored grain and grain products in the republic of Ireland. The Scientific Proceedings of the Royal Dublin Society Series B, 3 (20): 273-329.

El-Lakwah, F.A.M.; M.M. Kandil, G.H. Rady and Z.A. Halawa. (1993). Mites associated with stored foodstuffs in Qaliobia Governorate. Egypt. J. Appl. Sci., 8(7): 562-570.

Emmanouel, N.G.; C.T. Buchelos and C.T.E. Dukidis (1994). A survey on the mites of stored grain in Greece. J. Stored Prod. Res. 30 ( 2 ): 175-178.

Fisher, A. R. (1950). Statistical Methods for Research Worker. Oliver and Boyd, Edinburgh and London.

Genc, C. and A.I. Ozar (1986). Preliminary investigations on the mites found on stored products in Izmir. Turkiye Bitki Koruma Dergisi, 10(3): 175-183.

Hafez, S.M. (1977). Studies on Predaceous and Parasitic Mites of Stored Product Pests, pp.223-229, Ph.D. Thesis, Faculty of Agric. Ain. Shams University, Egypt.

Halawa, Z.A. (2003). Mites associated with stored foodstuffs in Alexandria Governorate. Bull. Soc. Ent. Egypte, 8: 47-58.

Hall, D.W. (1970). Handling and StorAge of Food Grains in Tropical and Subtropical Areas, 350pp. FAO Agricultural Development Paper No. 90, FAO, Rome.
Hoda, F.M.; M.E. El-Naggar; H.A. Taha and M.M. El-Beheiry (1990). Prostigmatid mites associated with stored products. Agric. Res. Review, 68(1): 7785.

Hughes, A.M. (1961). The mites of stored food. Tech. Bull. Min. Agric. Fish. 9: 287 pp.

Hughes, A.M. (1976). The Mites of Stored Food and Houses. Technical Bull 9: 400 pp. Minst. of Agric., Fish. \& Food, London.

Krantz, G.W. (1978). A Manual of Acarology. 509 pp. Oregon State University book stores, Inc. Corvallis, Oregon.

Li, L.; Q. Fan; L.S. Li and O.H. Fan (1997). A survey of food mites from four provinces of China. Systematic and Appl. Acarol. 2 : 247-250.

Mahmood, S.H. (1992). Mite fauna of stored grain seeds in Central Iraq. $J$. Stored Prod. Res. 28(3): 179-181.

Matsumoto, K.; M. Okamoto; H. Horikawa; K. Nkagawa and H. Yamaura. (1998). The effect of the different environmental conditions on the dispersion of grain and house dust mites (Acari: Astigmata). Med. Entomol. Zool., 49 (4): 291-300.

Rady, G. H. (1998). Revision of the genus Acarophenax Newstead and Duvall, 1918 (Acari.Tarsonemina: Acarophenacidae) in the world. With discription of new species from Egypt. Annals Agric. Soc. Moshtohor 36: 587-602

Schuster, R.O. and A.E. Pritchard. (1963). Phytoseiid mites of California. Hilgardia, 34 (7): 191-285.

Sinha, R.N. (1973). Ecology of storage. Ann.Technol. Agric. 22: 351-369.

Snedecor, G. W. and W. G. Cochran. (1980). Statistical Methods. $7^{\text {th }}$ Ed., pp. 264-267, Iowa State Univ. Press, Ames., Iowa, USA. 
Volgin, V.I. (1987). Acarina of the family Cheyletidae of the world. Vol. 10: 532 pp. Amerin Publishing Co. Pvt. Ltd., New Delhi.

Wafa, A.K.; M.A. Zaher, A.H. El-Kifl and M.A. Hegazy (1966a). Survey of stored grain and seed mites. Bull. Soc. ent. Egypte, 52: 225-232.

Wafa, A.K.; M.A. Zaher; A.H. El-Kifl and M.A. Hegazy. (1966b). Population density of mites found with stored wheat in Egypt. Bull. Soc. Ent. Egypte, 52: 233-239.

Waller, R.A. and D.B. Duncan (1969). A bayes rule for the symmetric multiple comparison problems. Amer. Statistical Assoc. 64: 1485-1503.

White, N.D.G.; L.P. Henderson and R.N. Sinha (1979). Effects of infestation by three stored product mites on fat acidity, seed germination and microflora of stored wheat. J. Econ. Ent., 72: 763-766.

Zaher, M.A. (1986). Predacious and nonphytophagous mites in Egypt (Nile valley and Delta). Pl. 480 Program USA Project No. EG-ARS-30 Grant No. FGEG-139: 518-567.

Zaher, M.A. and Z.R. Soliman (1971). Life history of the predatory mite Chey- letus malaccensis Oud. (Acarina: Cheyletidae). Bull. Soc., Ent. Egypte, 55: 49-53.

Zaher, M.A.; M.I. Mohamed and S.M. Abdel-Halim (1986). Incidence of mites associated with stored seeds and food products in upper Egypt. Exp. Appl. Acarol. 2 (1): 19-24.

Zdarkova, E. (1967). Stored food mites in Czechoslovakia. J. Stored Prod. Res., 3: 55-175.

Zdarkova, E. (1996). The effect of mites on germination of seed. Ochr. Rostlin. 32 (3): 175-179.

Zdarkova, E. (1998). Mite fauna of stored grain in the Czech Republic. Ochr. Rostlin, 34 (2): 49-52.

Zdarkova, E. and E. Horak. (1990). Preventive biological control of stored food mites in empty stores using Cheyletus eruditus (Shrank). Crop Protec., 9 (5) : 378-382.

Zdarkova, E.; C. Adler and M. Schoeller (1997). Personal experience with biological control of stored- food mites. Integrated protection of stored products. Proceedings of the meeting at Zurich, Switzerland. Bull. OILB SROP, 21 (3): 89-93. 


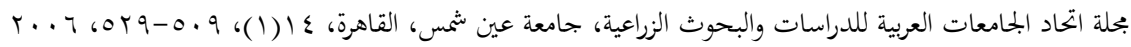

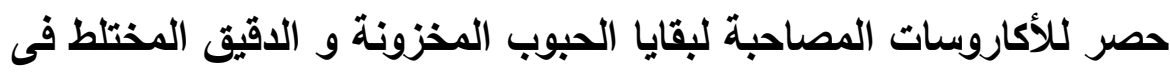
المخازن والمطاحن بالقاهرة الكبرى

[rs ]

\begin{abstract}
أحمد عيد عبد المجيد محجوب' - على ابراهيم بدوى '- عماد مرداش بلور' ا - قسم وقاية النبات- كلية الزراعة- جامعة عين شمس- شبرا الخيمة- القاهرة- مصر
\end{abstract}

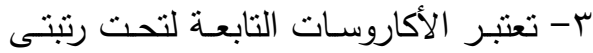
الأكتنيديدا و الأكاريديدا ذات نواجد سائد لتاني وثابت في بقايا الحبوب والدقيق المختلط

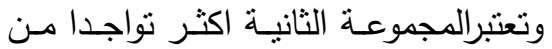
المجموعة الأولى. كان تواجد أكاروسات تحت رتبة الجاماسيدا بصورة عرضية.

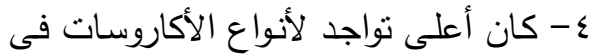

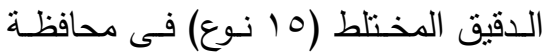

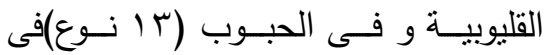

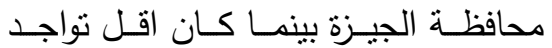
لأنـواع الأكاروسـات (0 أنـواع) فـى بقايـا الحبوب فى محافظة الجيزة.

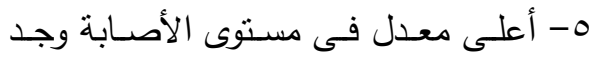

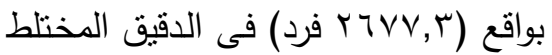

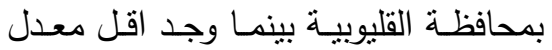

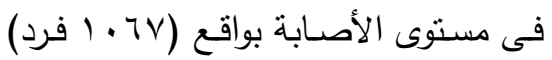

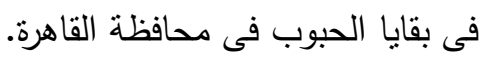

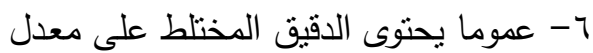

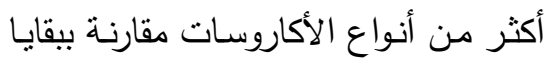

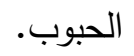

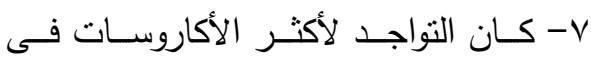
Pصلى الخريف والثتاء ماعدا

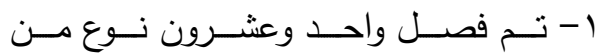

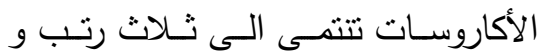

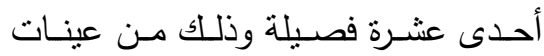
بقايـا الحبوب المخزونـة والدقيق المختلط والتى تم جمعها من المخازن و المطاحن

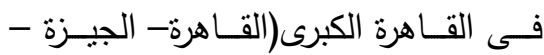
القليوبيـة) وكانت هذة الأكاروسـات عبارة

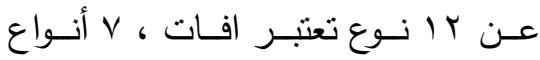
مفترسات ، r r نوع متطفلات r - تواجدت أنواع أكاروسات

Dermatophagoides farinae; Tyrophagous putrescentiae and Cheyletus malaccensis بصفة شـائعة وسـائدة فـى جميـع عينـات الحبوب والدقيق فى جميع المناطق بينما الأنواع Acarus siro; Acarophenax غالبا Pyemotes herfsi and tribolii كانت منواجدة ولكن أحيانا غاب البعض

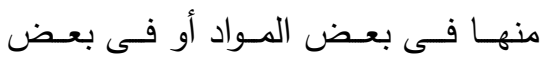
المناطق. الأنواع الأخرى المسجلة كاند متواجدة بصورة منفرقة. 
النسبية على ديناميكيـة التعداد ، وعلاقـة الأكاروسات المفترسـة بألأفات الأكاروسية

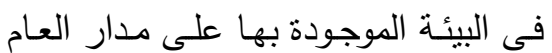

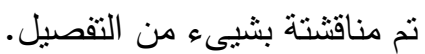

herfsi Acarophenax tribolii الصيف. - السيادة، التواجد، تأرجح التعداد، وكذلك

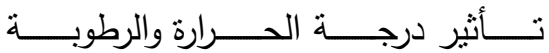

تحكيم: ا.د شريف مصطفى حافظ

I.د زينه رمضنان سليمان 